\title{
The Journal of Medicine and Philosophy
}

Editor: EDMOND D. PELLEGRINO

ISSN 0360-5310

Associate Editor: H. TRISTRAM ENGELHARDT, Jr.

The Journal of Medicine and Philosophy is sponsored by the Kennedy Institute of Ethics and explores the shared themes and concerns of philosophy and the medical sciences. Not since Galen's time has the contact between medicine and philosophy been so widespread; the Journal seeks to meet the challenge of this dialogue by providing a forum for philosophers, medical practitioners, educationists, and humanists to examine the problems and controversies stimulated by the engagement of these two disciplines.

Subscription Information

1984, Volume 9 (4 issues)

Institutional rate: Dfl. $105,-$ / US $\$ 40.50$ including postage and handling Private rate: Dfl. 55,- / US $\$ 19.50$ including postage and handling

Private subscriptions should be sent direct to the publishers.

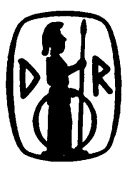

D. Reidel Publishing Company

P.O. Box 17, 3300 AA Dordrecht, The Netherlands 190 Old Derby St., Hingham, MA 02043, U.S.A.

\section{Endangered}

\section{Lives}

\section{Public health in Victorian Britain}

ANTHONY S. WOHL

\section{University Paperback}

'For those interested and concerned with the causes of the serious health problems of people in the developing world, Anthony Wohl's description of city life in Victorian Britain should be compulsory reading ... (It) is a fascinating book drawing on a wide range of publications and revealing a largely unknown aspect of life in the Victorian age.

Neu' Scientist

'His book is the culmination of many year's work on the issues faced by the Victorians. skilfully woven into an absorbing. and certainly evocative narrative.'

The Times Educational Supplement

448 pages

Paperback $\quad 0416.379508 \quad £ 7.95$

\section{Reproductive Rituals}

Perceptions of fertility in Britain from the sixteenth century to the nineteenth century.

\section{ANGUS MCIAREN}

Professor Mclaren discusses the various rules, charms, taboos and remedies employed to affect the processes of conception and gestation. Reproductive Rituals explains the social and cultural influences on fertility patterns which are central to our understanding of demographic change, and makes an important contribution to the history of the family: It is compulsive reading.

about 208 pages

Hardback (o $416 \quad 374506$ about $\$ 15.00$ Paperback o $41637+603$ about $\$ 5.95$

\section{METHUEN}

11 New Fetter Lane, London EC 4P 4EE 
Scarce and out-of-print books in the history of medicine

Please write for a copy
of my latest catalogue

Webb Dordick

15 Ash Avenue

Somerville, Massachusetts 02145

U.S.A.

(617) 776-1365

Business by mail only

\section{Books concerning the}

History of Medicine, Natural,

Pure and Applied Science

Catalogues issued-desiderata lists welcome

MICHAEL PHELPS
ANTIQUARIAN BOOKS
19 CHEIVERTON ROAD.PUINCY
LONDON SW15 IRN - ENGLAND

Folephone: (01-7855 6766 Cables: PHELOBOOKS LONDON SW 1.5 


\section{MEDICAL BOOKS}

Prints * Portraits

$$
\text { Old, RaRe, }
$$

\& OUt-OF-Print

\section{America's Largest Stock}

All items are fully catalogued and classified, American and European, dating from the 15th to the 20th centuries particularly classical and unusual works, with emphasis upon history, biography, and specialized medicine.

Lists issued in all fields of medicine.

We are eager to purchase small or large collections.

\section{ARGOSY BOOK STORES}

116 E. 59th St., N.Y., N.Y. 10022 , PL.3-445
F. E.

Whitehart

40 Priestfield Rd.

Forest Hill

London SE23 2RS

01-699 3225 or

0689-73560

our stock

covers the

period 1500

onwards and is

devoted

exclusively to

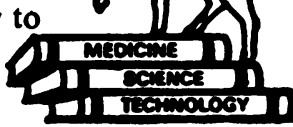

CATALOGUES ISSUED

Normal business hours or by appointment
Rare Books \& Manuscripts in the bistory of

Medicine \& the Sciences

BOUGHT · SOLD · APPRAISED

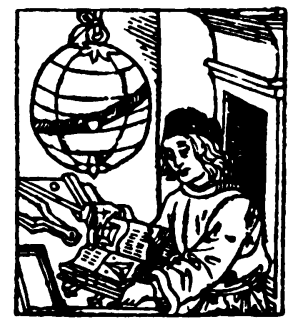

Send for our latest catalogue Jeremy Norman \& Co., Inc. 442 POST STREET

SAN FRANCISCO, CALIFORNIA 94102

$$
\text { (415) } 781-6402
$$

\section{Nigel ER Rillips}

Antiquarian books in the history of medicine and the health sciences.

Please send for my catalogue.

\section{RADCLIFFE SQUARE \\ PUTNEY HILL LONDON SW15 6BL ENGLAND}

Tel: 01-788 2664 